\title{
Wpływ leczenia ortodontycznego na jakość torów ruchów żuchwy w badaniach instrumentalnych T-scan i Zebris JMA
}

\author{
The effect of orthodontic treatment on the quality of mandibular \\ movement tracks in T-scan and Zebris JMA instrumental studies
}

\author{
1 Zakład Protetyki Stomatologicznej, Pomorski Uniwersytet Medyczny w Szczecinie \\ ${ }^{2}$ Zakład Ortodoncji, Pomorski Uniwersytet Medyczny w Szczecinie
}

DOI: http://dx.doi.org/10.20883/df.2016.7

\begin{abstract}
Streszczenie
W związku ze zwiększającą się częstością występowania, różnorodnością objawów oraz wzrostem intensywności przebiegu procesu chorobowego proste badania kliniczne wydają się być niewystarczające. Zastosowanie nowoczesnych, często skomplikowanych technik diagnostycznych jest niezbędne, zwłaszcza u pacjentów z nasilonymi objawami zaburzeń czynności układu stomatognatycznego, połączonych niejednokrotnie ze zmianami morfologicznymi. Wśród czynników wywołujących zaburzenia funkcjonowania układu stomatognatycznego wymienia się: zgryz urazowy, stres psychiczny, nawyki, ostre i przewlekłe urazy, zaburzenia czynnościowe mięśni oraz czynniki jatrogenne. Zgryz urazowy jako przyczyna budzi najwięcej kontrowersji, zwłaszcza w postaci pierwotnej wady ortodontycznej. W pracy przedstawiono przypadek młodej kobiety z rozpoznaniem ciężkiej dysfunkcji stawów skroniowo-żuchwowych, wywołanej niezaadoptowanym zgryzem urazowym, będącym konsekwencją nieleczonej, zębowej wady zgryzu. Przy pomocy urząazeń elektronicznych Zebris JMA oraz Tekscan dokonano monitoringu kinematyki żuchwy oraz rozkładu sił nacisku na łuki zębowe od rozpoznania do zakończenia leczenia. W obrazach wymienionych technik instrumentalnych przedstawiono skuteczność postępowania ortodontycznego jako metody w leczeniu i profilaktyce dysfunkcji stawów skroniowo-żuchwowych.
\end{abstract}

Słowa kluczowe: wady zgryzu, dysfunkcje ssż, techniki instrumentalne.

\begin{abstract}
As a result of the increasing frequency and diversity of symptoms, as well as an increase in the intensity of the disease process, simple clinical studies tend to be insufficient. The use of modern, often complex diagnostic techniques is essential, especially in patients with severe symptoms of stomatognathic system dysfunction, often combined with morphological changes. The factors causing dysfunction of the stomatognathic system include the following: bite disorders, mental stress, habits, acute and chronic injuries, functional muscle disorders, and iatrogenic factors. Bite disorders are a cause which raises the most controversy, especially those in the form of a malocclusion. We present a case of a young woman diagnosed with severe dysfunction of the temporomandibular joints, caused by traumatic unaligned bite, which is a consequence of untreated dental malocclusion. With the help of electronic devices, Zebris JMA and Tekscan, the kinematics of the mandible and the distribution of compressive forces on the dental arches from diagnosis to completion of treatment were monitored. Images produced using the instrumental techniques show the effectiveness of orthodontic procedures as a method for the treatment and prevention of temporomandibular joint dysfunction.
\end{abstract}

Keywords: malocclusion, TMJ dysfunction, instrumental techniques.

\section{Wstęp}

W dobie wzrastającej częstości występowania, różnorodności objawów oraz intensyfikacji przebiegu procesu chorobowego proste badania kliniczne wydają się być niewystarczające. Zastosowanie nowoczesnych, często skomplikowanych technik diagnostycznych jest niezbędne, zwłaszcza u pacjentów z nasilonymi objawami zaburzeń czynności układu stomatognatycznego, połączonych niejednokrotnie ze zmianami morfologicznymi.

Dysfunkcje układu stawowo-mięśniowego i zębowego, zwane często zaburzeniami czynno- ściowymi układu ruchowego narządu żucia (URNŻ), wciąż stanowią w praktyce lekarza stomatologa poważny problem tak diagnostyczny, jak i terapeutyczny. Według najnowszych badań epidemiologicznych, przeprowadzonych w krajach wysoko rozwiniętych, przyjmuje się, że nawet około $75-90 \%$ populacji cierpi na zaburzenia czynnościowe układu stomatognatycznego, jak twierdzą Carlsson [1] Macfarlane [2] oraz Rugh [3]. Istnieje również grupa badaczy, która uważa, że przypadłość ta występuje znacznie częściej u kobiet niż u mężczyzn [4-6]. Podstawowe objawy dysfunkcji narządu żucia to ból samoistny 
okolicy stawów skroniowo-żuchwowych (ssż) lub podczas ruchów żuchwy, ograniczenie jej ruchomości i związane z tym utrudnione lub bolesne żucie, przeskakiwanie i trzaski w ssż podczas ruchu, w nasilonych postaciach szczękościsk oraz bóle głowy i karku. Wśród czynników sprzyjających generowaniu zaburzeń układu stomatognatycznego wymienia się stres psychiczny, złe nawyki, ostre i przewlekłe urazy, nieprawidłowe funkcjonowanie mięśni, urazową okluzję, czynniki jatrogenne, schorzenia psychiczne oraz zaburzenia hormonalne, a także uogólnione choroby stawów, co potwierdziły badania Greeka [7], LeResche'a i in. [8], Egermark-Erikssona i in. [9] oraz Curcica [10] i Więckiewicz [11]. Stawy skroniowo-żuchwowe są najczęściej używanymi stawami w organizmie człowieka. Biorą udział w wielu fizjologicznych czynnościach, takich jak przyjmowanie pokarmów, artykulacja dźwięków (mowa, śpiew), ziewanie, a nawet wyrażanie emocji. Stwierdzono, że w ciągu doby łuki zębowe są w kontakcie przez ok. 30 min - głównie podczas przełykania śliny. Zaburzenia okluzji (occlusal interferences) definiuje się jako nieprawidłowe kontakty zębów pojedynczych lub ich grup, utrudniające lub uniemożliwiające stabilny i harmonijny kontakt pozostałych zębów przeciwstawnego łuku zębowego w okluzji statycznej lub dynamicznej, co może prowadzić do powstawania dysfunkcji lub parafunkcji w układzie stomatognatycznym [12, 13]. Częstość diagnozowania dysfunkcji układu ruchowego narządu żucia w grupie osób $z$ wadami zgryzu jest według wielu autorów istotnie skorelowana. Uznają oni warunki okluzyjne za jeden z istotnych czynników w etiologii dysfunkcji [14-17]. Istnieją również propagatorzy odmiennego zdania twierdzący, iż zaburzenia zwarcia (niezależnie od stopnia nasilenia) nie wpływają bezpośrednio na częstość występowania dysfunkcji układu ruchowego narządu żucia [18-20]. Zdaniem autorów niniejszego opracowania nieprawidłowe kontakty zębowe spowodowane np. utratą zębów, bruksizmem, nie leczoną próchnicą, wadą zgryzu lub brakami zębowym mogą być źródłem naprężeń w stawach skroniowo-żuchwowych, które z czasem prowadzą do uruchomienia kaskady niekorzystnych zdarzeń, a w konsekwencji do rozwoju poważnego schorzenia.

\section{Cel}

Celem pracy była ocena wpływu warunków okluzji statycznej i dynamicznej na jakość torów ruchów żuchwy.

\section{Materiał i metoda}

Założenie zrealizowano na drodze jakościowej i ilościowej analizy wybranych parametrów ruchów żuchwy, zarejestrowanych u pacjentki z zaawansowaną dysfunkcją narządu żucia spowodowaną nieleczoną wadą zgryzu. Badania kliniczne przeprowadzono przed i po leczeniu ortodontycznym z zastosowaniem wyspecjalizowanego elektronicznego łuku twarzowego Zebris JMA oraz urządzenia do badań rozkładu sił nacisku Tekscan. Zebris JMA (Rycina 1) to złożo-

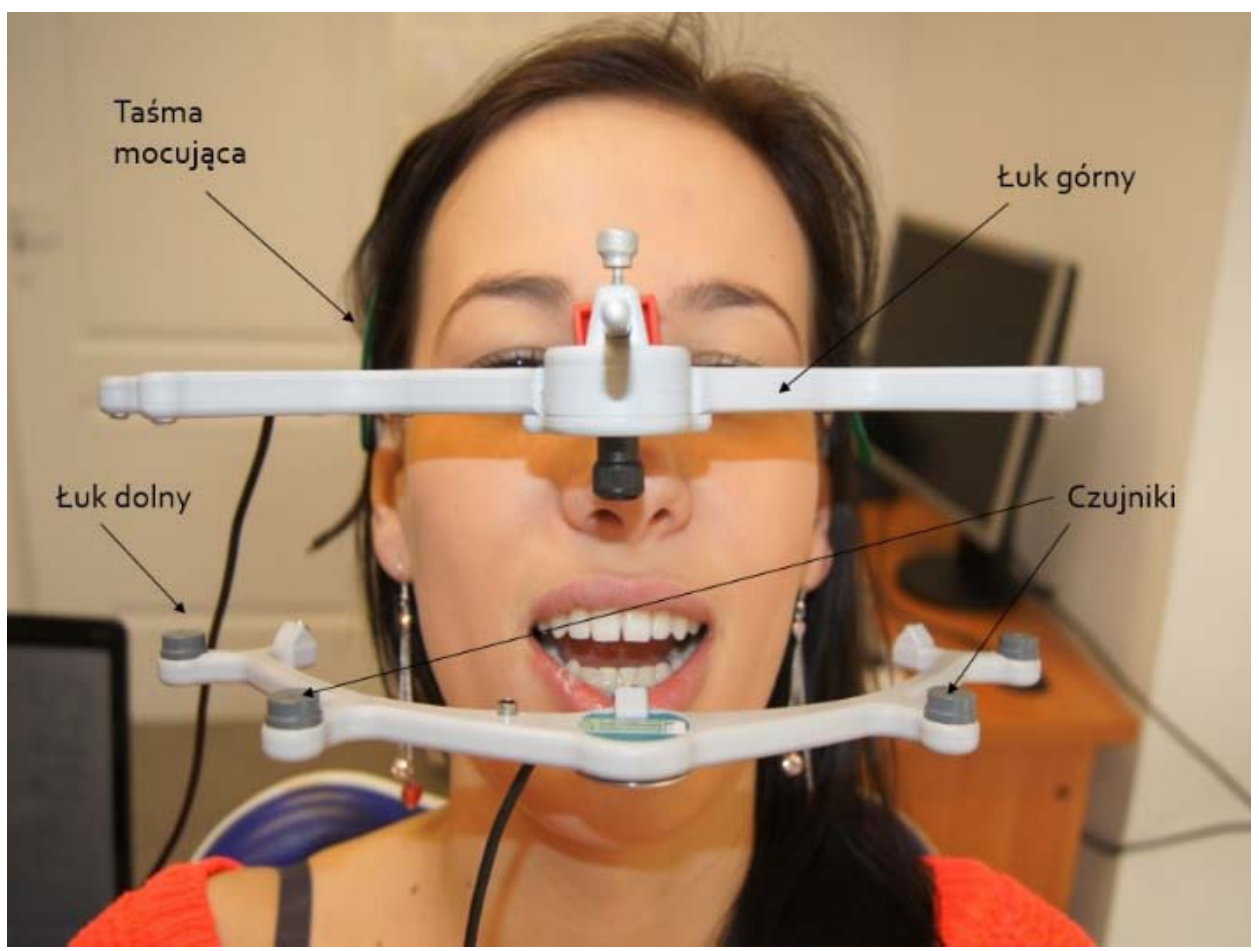

Rycina 1. Rejestracja ruchów żuchwy przy pomocy urządzenia Zebris JMA

Figure 1. Recording mandibular movements using a Zebris JMA device 
ny system rejestrujący, sterowany komputerem, którego spektrum zastosowań w diagnostyce funkcjonalnej zostało znacznie poszerzone. Aparat posiada dwa sztywne łuki pomiarowe, których montaż we właściwej pozycji jest zdecydowanie uproszczony. Obręcz twarzową, łuk górny (1) zakłada się na nos i mocuje z tyłu głowy nad uszami przy użyciu plastikowej taśmy (2). Czujniki pomiarowe (3) zlokalizowane są w ruchomym łuku (4), który musi być dokładnie przymocowany okołozwarciowo do powierzchni wargowej przednich zębów żuchwy. Przy czym połączenie czujnika z zębami nie może przeszkadzać podczas rejestracji ruchów funkcjonalnych prawidłowego zaguzkowania. Zamontowanie elementów pomiarowych nie nastręcza trudności, gdyż przygotowanie do badania przebiega szybko i sprawnie. Niewielki ciężar dolnego łuku, wynoszący zaledwie $20 \mathrm{~g}$, nie męczy ani nie obciąża nadmiernie pacjenta. Czujniki znajdujące się w dolnym, ruchomym łuku rejestrują zmianę natężenia fal ultradźwiękowych, generowanych z częstotliwością $900 \mathrm{~Hz}$ przez nieruchome nadajniki zlokalizowane w łuku górnym. Efektem tego są precyzyjne, rejestrowane $z$ dokładnością $\pm 0,1 \mathrm{~mm}$, trójwymiarowe trajektorie, po jakich przemieszczają się głowy wyrostków kłykciowych oraz zęby sieczne. Przebieg badania jest stosunkowo krótki i prosty. Po zamontowaniu tuku pomiarowego pacjent wykonuje kilkanaście ruchów żuchwą, podczas których układ sensoryczny urządzenia rejestruje trajektorie odwodzenia i przywodzenia, obustronne ruchy laterotruzyjne oraz ruchy protruzyjne. W trakcie badania komputer w czasie rzeczywistym zapisuje dane pomiarowe. Ważną funkcją omawianej aparatury jest możliwość wprowadzenia dodatkowych punktów orientacyjnych, charakteryzujących osobniczo zmienne cechy budowy geometrycznej części twarzowej czaszki badanego, efektem czego jest wieloparametryczna analiza zwarcia oraz pracy stawów. Dane antropometryczne twarzoczaszki stanowią ważny punkt odniesienia, wykorzystywany podczas formułowania diagnozy. System T-scan II (Tekscan) umożliwia jakościową i ilościową ocenę zaburzeń okluzyjnych i zalecany jest do analizy okluzji uzębienia naturalnego oraz uzupełnień protetycznych.

Przykładem nasilonej dysfunkcji ssż jako następstwa niewielkiej wady zgryzu jest zgryz krzyżowy w obrębie II zęba przedtrzonowego dolnego.

\section{Opis przypadku}

Pacjentka PP (lat 24) zgłosiła się w marcu 2011 roku do Katedry i Zakładu Protetyki Stomatologicznej z prośbą o pomoc. Uskarżała się na głośne, dobrze słyszalne przez otoczenie trzaski występujące przy jedzeniu, którym nie towarzyszyły żadne dolegliwości bólowe. Okresowo pojawiały się tylko trudności w otwieraniu ust. W badaniu kli- nicznym zewnątrzustnym nie stwierdzono wzmożonego napięcia mięśni ani tkliwości palpacyjnej badanych okolic. Potwierdzono jedynie głośne i naprzemienne trzaski w obu ssż, zaznaczone wyraźniej w prawym stawie oraz nieprawidłowy tor odwodzenia i przywodzenia żuchwy ze znacznym, zdeklarowanym, prawostronnym jej zbaczaniem. W badaniu wewnątrzustnym odnotowano również nieznaczne ograniczenie wielkości szpary rozwarcia ust $(35 \mathrm{~mm})$ mierzonej pomiędzy brzegami siecznymi siekaczy centralnych oraz niewielką wadę zgryzu w postaci zgryzu krzyżowego w obrębie ll zęba przedtrzonowego dolnego po stronie prawej. Wszystkie występujące objawy pacjentka określała jako zdecydowanie bezbolesne, ale niesłychanie uciążliwe, deprymujące i krępujące, zwłaszcza w towarzystwie. $\mathrm{W}$ badaniu stawów skroniowo-żuchwowych szczególną uwagę zwrócono na brak bolesności palpacyjnej okolicy stawu oraz występowanie zjawisk akustycznych, takich jak trzeszczenia i trzaski. Ponadto badano palpacyjnie mięśnie żucia: żwacze i skroniowe, oceniając ich stopień napięcia, tkliwość oraz obecność punktów spustowych - TrPs (trigger points). Ocena kliniczna potwierdziła dane pozyskane drogą anamnezy: brak zmian w napięciu i dolegliwości ze strony układu mięśniowego. Mając na uwadze, iż w większości przypadków badanie kliniczne jest niewystarczające i musi być uzupełniane dodatkowymi badaniami z zastosowaniem specjalistycznej aparatury, oraz ze względu na złożony charakter objawów pacjentkę poddano wnikliwej diagnostyce czynnościowej z zastosowaniem zewnątrzustnej analizy modeli diagnostycznych oraz elektronicznych systemów rejestrujących Zebris JMA oraz Tekscan (Rycina 2). W dalszej kolejności poddano ocenie zarejestrowane trajektorie wolnych i okluzyjnych ruchów żuchwy.

Analiza modeli gipsowych potwierdziła podejrzewane w badaniu klinicznym zaburzenia okluzji powodujące „spychanie” żuchwy w zwarciu centralnym w stronę lewą oraz zaburzenia w okluzji dynamicznej, powodujące asymetryczny rozkład sił i lewostronne prowadzenie grupowe $z$ cechami okluzji urazowej, co potwierdziły badania urządzeniem T-scan (Rycina 3).

Wyniki badań czynnościowych ruchów żuchwy, zarejestrowane aparatem Zebris potwierdziły wcześniejsze przypuszczenia o poważnym nasileniu schorzenia (Rycina 4).

Rycina 4 przedstawia obraz charakterystyczny dla przemieszczenia krążka z zablokowaniem w prawym stawie skroniowo-żuchwowym - znaczne ograniczenie składowej translacyjnej trajektorii prawej głowy żuchwy oraz związane z tą sytuacją kompensacyjne zaburzenie ruchomości w stawie lewym. Uzupełnieniem podejrzenia tego rodzaju dyslokacji była również ilościowa analiza zakresu ruchów w stawach (Rycina 5). 

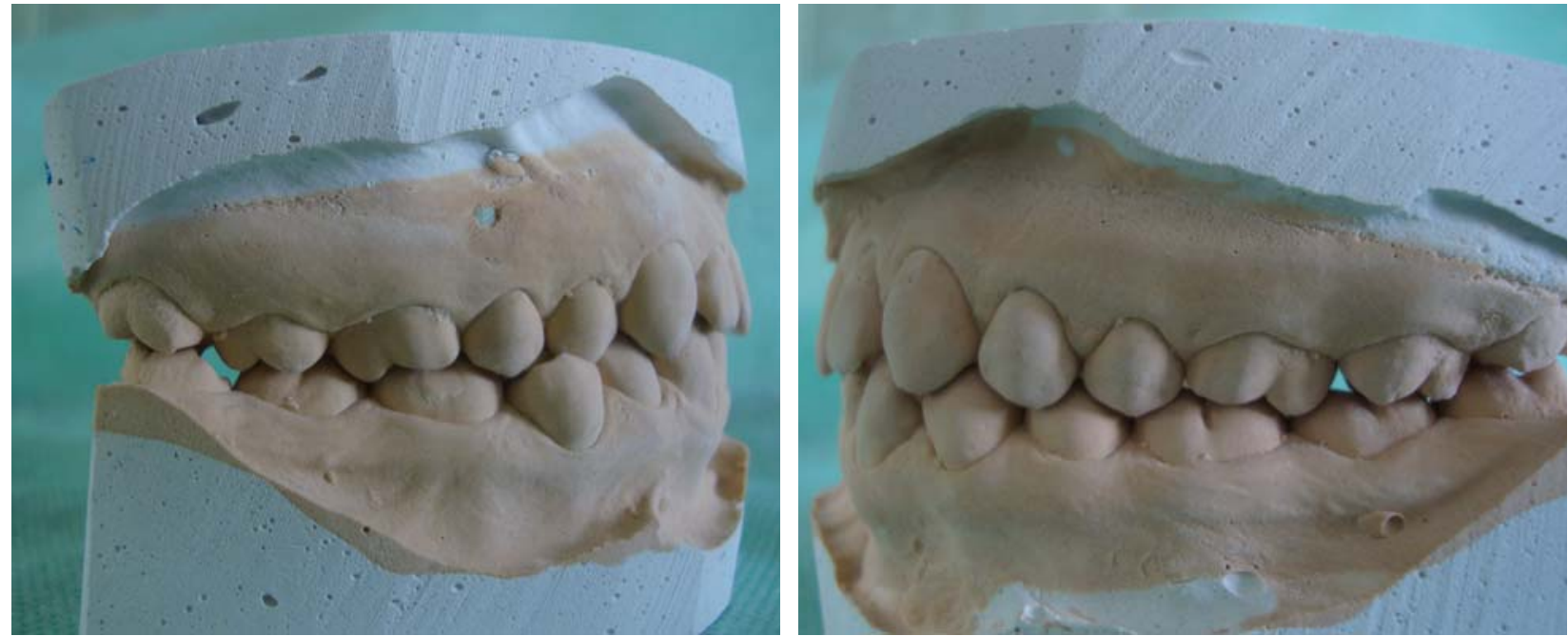

Rycina 2. Modele diagnostyczne pacjentki przed leczeniem

Figure 2. Diagnostic plaster models of a patient before treatment

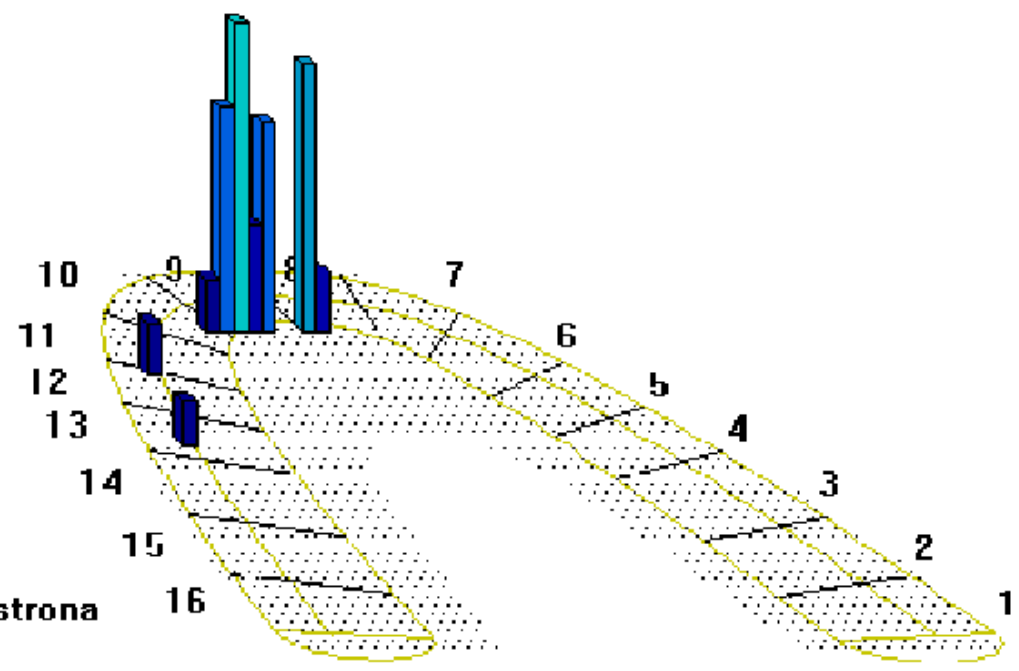

Lewa strona $16 \quad-16$ 1

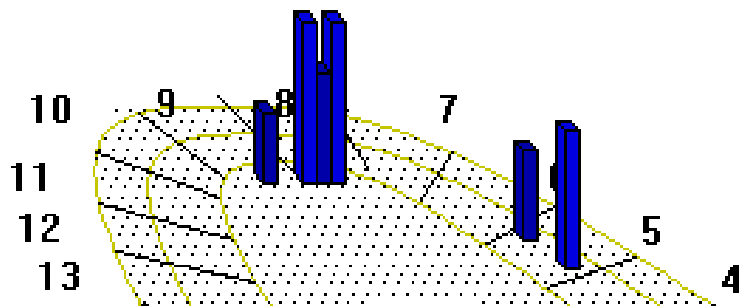

14

15

Lewa strona

16
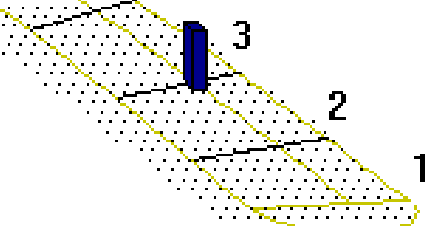

Rycina 3. Wynik badania rozkładu nacisków na łuki zębowe w urządzeniu T-scan

Figure 3. Pressure distribution in dental arches obtained with a T-scan 


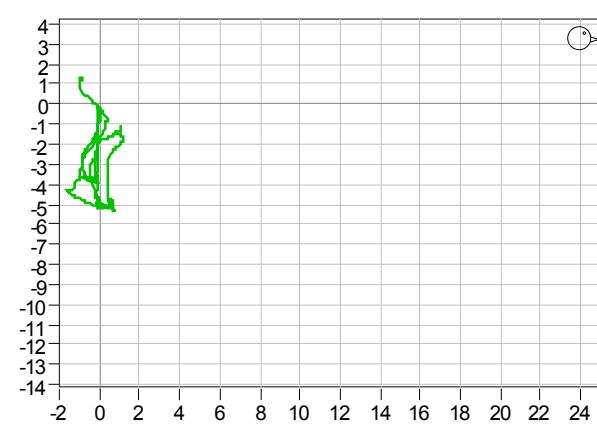

A

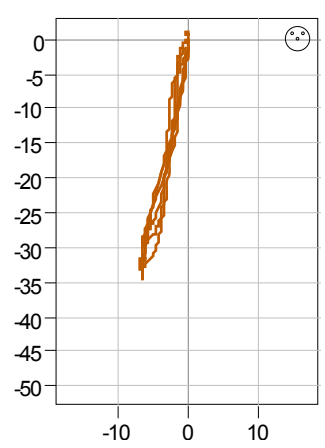

B

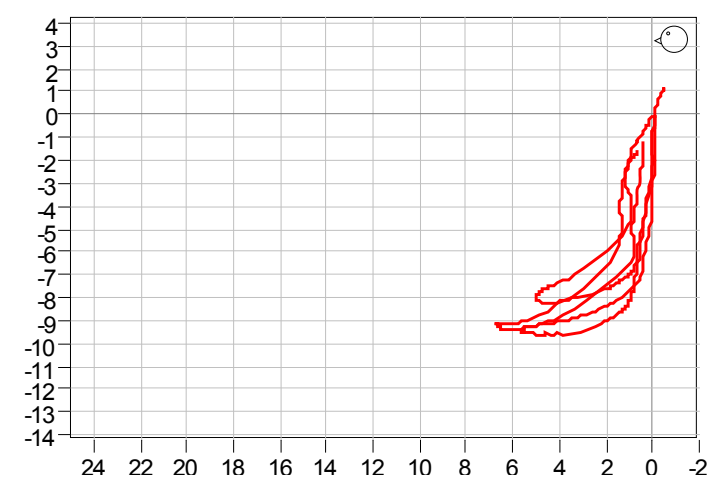

C

Rycina 4. Zapis graficzny ruchu wyrostków kłykciowych (A - prawy; C - lewy; B - punkt sieczny) aparatem Zebris JMA - stan przed leczeniem

Figure 4. Records of condylar processes movements ( $A$ - right; $C$ - left; $B$ - incision point) obtained with a Zebris device - before treatment

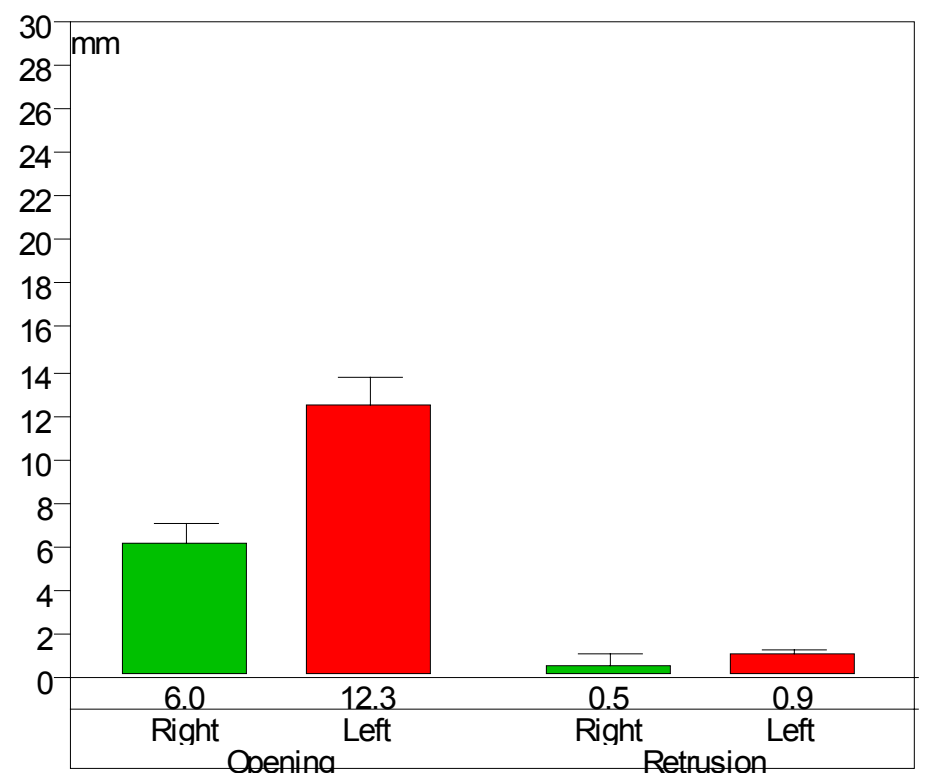

Rycina 5. Zakres ruchu głów wyrostków kłykciowych żuchwy wyciąg z raportu generalnego Zebris JMA

Figure 5. Range of condylar processes movements - extract from Zebris JMA general report

Z zaprezentowanego wyniku jednoznaczne wynika, iż mamy do czynienia ze znacznym ograniczeniem możliwości ruchu translacyjnego - doprzedniego przemieszczania prawego wyrostka kłykciowego żuchwy. Ze względu na młody wiek pacjentki, charakter zaburzeń oraz znaczny stopień ich nasilenia zdecydowano, że jedynie słusznym postępowaniem terapeutycznym będzie likwidacja urazowej okluzji drogą leczenia ortodontycznego z zastosowaniem aparatów stałych. Pacjentka bardzo dobrze zniosła trudy leczenia a wykonane w styczniu 2014 roku badania kontrolne wykazały całkowitą i znaczącą poprawę tak w aspekcie jako- ści ruchów żuchwy, jak i zakresów, a także poprawę okluzji statycznej, jak i dynamicznej (Ryciny 6 i 7).

Rycina 6 przedstawia utworzone na drodze leczenia ortopedycznego prawidłowe stosunki łuków zębowych w okluzji dynamicznej - prowadzenie kłowe po obu stronach oraz prawidłowy, niezaburzony ruch protruzyjny. Na rycinie $7 \mathrm{ob}-$ serwujemy natomiast właściwy zarówno co do kształtu, jak i zakresów graficzny obraz ruchu wyrostków kłykciowych oraz punktu siecznego, zarejestrowany urządzeniem Zebris JMA, charakterystyczny dla osobników zdrowych bez jakichkolwiek dysfunkcji. 

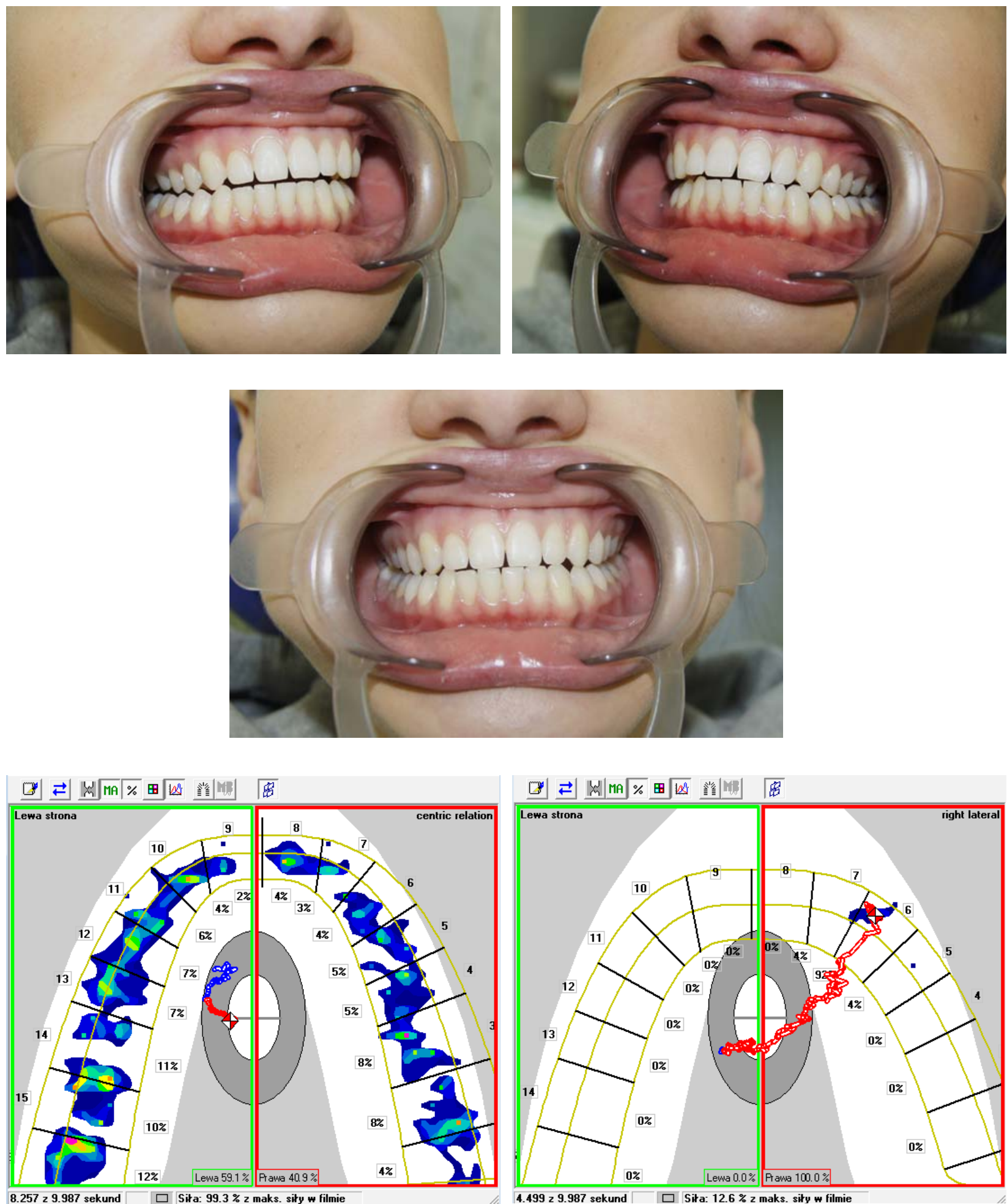

Rycina 6. Obraz kliniczny i graficzna rejestracja aparatem Tekscan ruchów laterotruzyjnych i protruzji po leczeniu ortodontycznym aparatem stałym

Figure 6. Clinical image and graphic record of lateral and protrusion movements obtained with a Tekscan device - after treatment with a fixed orthodontic appliance 


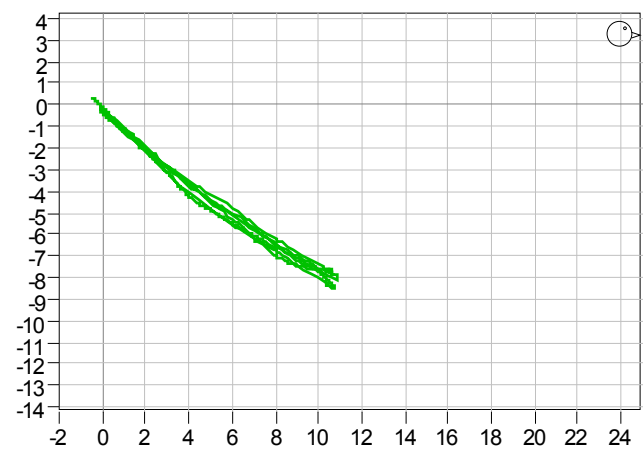

A

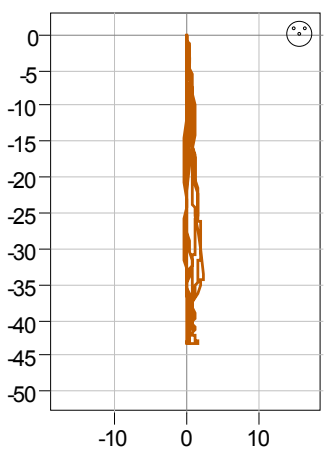

B

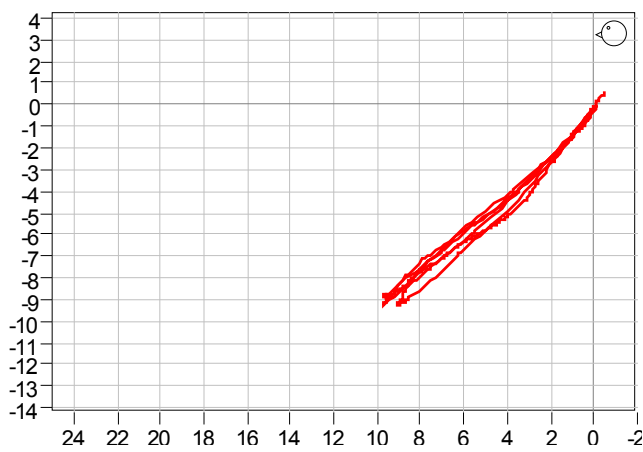

C

Rycina 7. Graficzny zapis ruchu odwodzenia po leczeniu - całkowita poprawa jakości i zakresu ruchów głów wyrostków kłykciowych (A - prawy; C - lewy) i punktu siecznego (B)

Figure 7. Records of abduction movements after treatment - total improvement quality and range of condylar process heads ( $A$ - right; $C$ - left; $B$ - incision point)

\section{Podsumowanie}

Podstawowe znaczenie w rozpoznawaniu dysfunkcji narządu żucia odgrywa wnikliwa anamneza oraz badanie kliniczne. Rzetelnym wskaźnikiem prawidłowej czynności mięśni narządu żucia oraz elementów stawów skroniowo-żuchwowych jest przede wszystkim analiza wolnych ruchów żuchwy [21, 22]. Badanie kliniczne jest niezbędne zarówno w diagnozowaniu dysfunkcji narządu żucia, jak i w ocenie wyników przebiegu leczenia. Analiza swobodnych ruchów żuchwy powinna być przeprowadzana w dwóch aspektach: jakościowym i ilościowym. Musi uwzględnić zarówno zakresy ruchów żuchwy (odwodzenia, przywodzenia, wysuwania i cofania oraz bocznych), jak i tory, po których poruszają się głowy wyrostków kłykciowych oraz punkt sieczny z jednoczesnym odniesieniem do towarzyszących im trzasków (i/lub przeskoków) w ssż [23, 24]. Deformacja torów wolnych ruchów żuchwy oraz towarzyszące objawy akustyczne wywodzące się ze ssż są pierwszymi objawami przemieszczeń krążków. Nieuwzględnienie ich przyczyn przed planowanym leczeniem ortodontycznym lub protetycznym u młodocianych może być przyczyną jatrogennego bólowego zespołu dysfunkcji narządu żucia [21, 25-29]. Nawrocka-Furmanek ze wsp. w swoich badaniach obserwowała częstość występowania dysfunkcji w grupach osób z poszczególnymi wadami zgryzu: poprzecznymi, przednio-tylnymi, pionowymi, wielopłaszczyznowymi oraz w grupie osób z nieprawidłowościami zębowymi i stwierdziła znamienny związek częstości występowania wad zgryzu i dysfunkcji układu ruchowego narządu żucia pod postacią dodatniej korelacji pomiędzy objawami akustycznymi i zaburzeniami ruchów żuchwy. Z doniesień literaturowych wynika, że sztucznie wytwarzane przeszkody okluzyjne powodują zmiany w przebiegu torów swobodnych ruchów żuchwy i wzorach skurczu mięśni żucia. Ponadto wykazywano, że eksperymentalne przeszkody zwarciowe wy- woływały krótkotrwałe objawy kliniczne, takie jak ból i nadwrażliwość mięśni, bóle głowy i trzaski w stawach skroniowo-żuchwowych lub przejściową zwiększoną ruchomość zębów lub nadwrażliwość miazgi [30-32]. Tak jak w opisywanym przypadku odgłosy akustyczne często stanowią jedyny objaw będący dowodem bezbólowej postaci dysfunkcji, świadczącym o zaburzeniu wzajemnych stosunków wewnątrzstawowych w ssż [33]. Oko badającego nie jest detektorem doskonałym, dlatego też konieczne wydaje się rejestrowanie trajektorii ruchów żuchwy, zwłaszcza w przypadku młodych chorych, u których planowane jest leczenie ortodontyczne, trwale zmieniające warunki okluzji. Badanie z wykorzystaniem elektronicznych systemów rejestrujących, wspomaganych komputerowo i nowoczesnych technik radiologicznych stanowi doskonałe uzupełnienie klinicznych dociekań nad przyczynami dysfunkcji [34-35]. Posiadanie tego rodzaju zapisów w dokumentacji medycznej stanowi nie tylko podstawę rozpoznania zaburzenia, ale jest również dowodem skuteczności postępowania terapeutycznego oraz znakomitym materiałem motywacyjnym i edukacyjnym tak dla pacjentów, jak i lekarzy.

\section{Oświadczenia}

Oświadczenie dotyczące konfliktu interesów

Autorzy deklarują brak konfliktu interesów w autorstwie oraz publikacji pracy.

\section{Źródła finansowania}

Autorzy deklarują brak źródeł finansowania.

\section{Piśmiennictwo}

[1] Carlsson C. Epidemiology and treatment Reed for temporomandibular disorders. J Orofac Pain. 1999;13:232-237.

[2] Macfarlane T, Glenny A, Worthington H. Systematic review of population-based epidemiological studiem of orofacial pain. J Dent. 2001;29:451-467.

[3] Rugh J, Kolberg W. Oral status in the United States. Temporomandibular disorders. J Dent Educ. 1985;49:398. 
[4] Egermark, Carlsson GE, Magnusson T. A 20-year longitudinal study of subjective symptoms of temporomandibular disorders from childhood to adulthood. Acta Odont Scand. 2001;59(1):40-48.

[5] Magnusson T, Egermark I, Carlsson GE. A longitudinal epidemiologic study of signs and symptoms of temporomandibular disorders from 15 to 35 years of age. J Orof Pain. 2000;14(4):310-319.

[6] Lagerstrom L, Egermark I, Carlsson GE. Signs and symptoms of temporomandibular disorders in 19-year-old individuals who have undergone orthodontic treatment. Swedish Dental J. 1998;22(5-6):177-186.

[7] Greek C. The etiology of temporomandibular disorders: implications for treatment. J Orofac Pain. 2001;15(2):93105.

[8] LeResche L, Dworkin S, Saunders K. Is postmenopausal hormone use a risk factor for TMD? J Dent Res. 1994;73:186

[9] Eriksson E, Carlsson, Magnusson T. A long term epidemiological study of the relationship between occlusal facto rand mandibular dysfunction in children and adolescents. J Dent Res. 1987;66:67-71.

[10] Curcic ZA. Ankylosing spondylitis initiated sa a reactive arthritis. Ann Rheum Dis. 2001;60(Suppl. 1):216.

[11] Więckiewicz M, Paradowska A, Kawala B, Więckiewicz W. SAPHO Syndrome as a Possible Cause of Masticatory System Anomalies - a Review of the Literature. Adv Clin Exp Med. 2011;20(4):521-525.

[12] Karasiński A, Baron S, Kokot T. T-scan System. Urządzenie do komputerowej analizy zwarcia. Prot Stom. 2000;1(2):63-70.

[13] McNeill Ch. Science and Practice of occlusion. Quintessence. Chicago-Berlin-London-Tokyo, 1997.

[14] Barker DK. Occlusal interferences and temporomandibular dysfunction. Gen Dent. 2004;52(1):56-61, quiz 62.

[15] Schiffman EL, Fricton JR, Haley D. The relationship of occlusion, parafunctional habits and recent life events to mandibular dysfunction in a non-patient population. J Oral Rehabil. 1992;19(3):201-223.

[16] Panek H. Materiały Zjazdowe Konferencji Międzynarodowej Wschód-Zachód, Warszawa, 2006.

[17] Egermark I. Ronnerman A. Temporomandibular disorders in the active phase of orthodontic treatment. J Oral Rehabil. 1995;22(8):613-618.

[18] Ahlberg JP, Kovero OA, Hurmerinta KA, Zepa I, Nissinen $\mathrm{MJ}$, Kononen $\mathrm{MH}$. Maximal bite force and its association with signs and symptoms of TMD, occlusion, and body mass index in a cohort of young adults. Cranio. 2003;21(4):248-252.

[19] Gesch D, Bernhardt O, Kirbschus A. Association of malocclusion and functional occlusion with temporomandibular disorders (TMD) in adults: a systematic review of population-based studies. Quintessence International. 2004;35(3):211-221.

[20] De Boever JA, Carlsson GE, Klineberg IJ. Need for occlusal therapy and prosthodontic treatment in the management of temporomandibular disorders. Part II. Tooth loss and prosthodontic treatment. Journal of Oral Rehabilitation. 2000;27(8):647-659.

[21] Kleinrok M. Zaburzenia czynnościowe układu ruchowego narządu żucia. Sanmedia, Warszawa 1992.

[22] Kleinrok M, Litko M, Borowicz J, Sarna-Boś K, Kuroń-Opalińska I, Kleinrok J. Analiza ruchu opuszczania żuchwy u chorych ze złożonymi przemieszczeniami krążka stawowego stawu skroniowo-żuchwowego. Prot Stom. 2004;LIV(3):145-151.

[23] Kleinrok M, Kleinrok J. Podział i rozpoznawanie kliniczne przemieszczeń krążka stawowego stawu skroniowo-żu- chwowego w maksymalnym zaguzkowaniu zębów. Prot Stom. 2000;4:185-194.

[24] Kleinrok M, Litko M, Borowicz J, Sarna-Boś K, Kuroń-Opalińska I, Kleinrok J. Analiza ruchu opuszczania żuchwy u chorych ze złożonymi przemieszczeniami krążka stawowego stawu skroniowo-żuchwowego. Prot Stom. 2004;LIV(3):145-151

[25] Wigdorowicz-Makowerowa N, Panek H, Marek H, Maślanka T, Płonka K, Pałacha A. Zaburzenia czynnościowe narządu żucia u dzieci ze szkół podstawowych m. Wrocławia. Prot Stom. 1978;XXVIII(1):21-25.

[26] Ohno H, Morinushi T, Ohno K, Ogura T. Comparative subjective evaluation and prevalence study of TMJ dysfunction syndrom in Japanese adolescents based on clinical examination. Community Dent Oral Epidemiol. 1988;6(2):122-126.

[27] Wahlund K. Temporomandibular disorders in adolescents. Epidemiological and methological studies and a randomized controlled trial. Swed Dent J. 2003;164:2-64.

[28] Siemińska-Piekarczyk B, Zadurska M, Biedrzycka E, Pietrzak-Bilińska B, Zwierzchowska-Walendziak H, Prasek-Czerniakowska M, Szymańska-Kubal D, Piotrowska M. Etiologia i objawy kliniczne bruksizmu u dzieci i młodzieży na podstawie piśmiennictwa i własnych obserwacji. Czas Stom. 1998;LI(1):47-54.

[29] Kleinrok J, Kleinrok M. Jatrogenny bólowy zespół dysfunkcji narządu żucia po leczeniu protezami stałymi. Prot Stom. 2001;LI(5):265-273.

[30] Kerstein RB, Wright NR. Electromyographic and computer analyses of patients suffering from chronic myofascial paindysfunction syndrome: before and after treatment with immediate complete anterior guidance development. J Prosthet Dent. 1991;66(5):677-686.

[31] Kobayashi Y, Shiga H. The path of chewing movement before and after experimental occlusal interference. Front Med Biol Eng. 1991;3(3):193-198.

[32] Shiau YY, Syu JZ. Effect of working side interferences on mandibular movement in bruxers and non-bruxers. J Oral Rehabil. 1995;22(2):145-151.

[33] Kleinrok M, Nowicka-Dudek K, Kleinrok J, Hawryluk E, Kobyłecka E. Badania nad zależnością pomiędzy przemieszczeniem krążka stawowego a ułożeniem głowy żuchwy w stawie skroniowo-żuchwowym. Prot Stom. 2000;L(2):71-79.

[34] Kijak E, Lietz-Kijak D, Frączak B, Wilk G. Zastosowanie zdjęć rentgenowskich i elektronicznych badań czynnościowych w diagnostyce dysfunkcji stawów skroniowo-żuchwowych. Mag Stomatol. 2012;XXII(5):28-33.

[35] Panek H. Zastosowanie systemów komputerowych w diagnostyce zaburzeń funkcjonalnych narządu żucia. Prot Stom. 2003;LIII(2):77-84.

Zaakceptowano do edycji: 2016-04-28 Zaakceptowano do publikacji: 2016-05-06
Adres do korespondencji:
Edward Kijak
Katedra i Zakład Protetyki Stomatologicznej
Pomorski Uniwersytet Medyczny w Szczecinie
ul. Powstańców Wielkopolskich 72, 70-111 Szczecin
tel.: 914661714
e-mail: zd.protetyki.stom@sci.pam.szczecin.pl 